Konstantin

Paustóvski em

foto dos anos 40

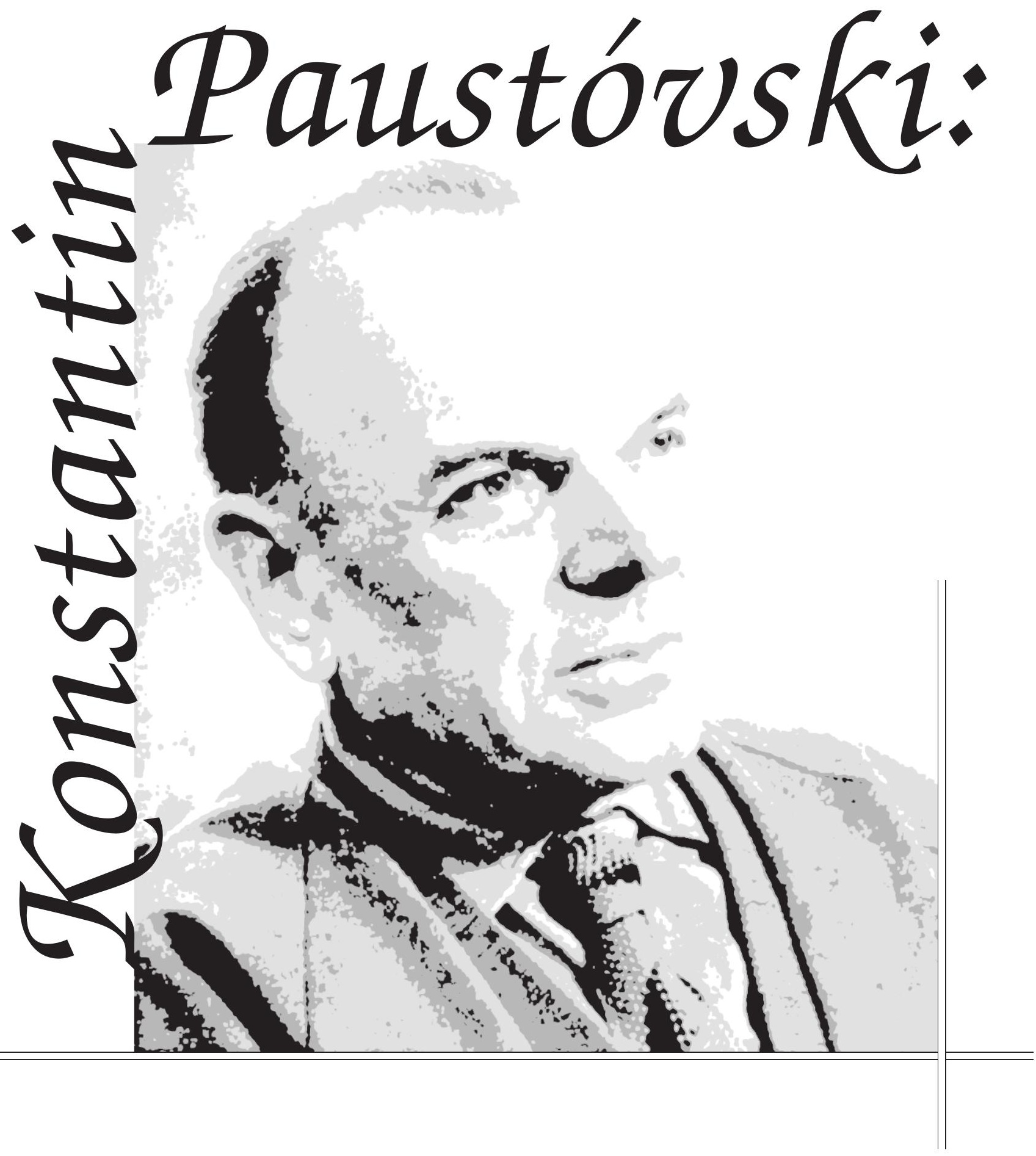


NOÉ SILVA é professor de Literatura Russa da

\section{a força eficiente e vital do romantismo}

efervescência do pensamento e as transformações radicais, refletidas nas artes, assinalaram o fim do século XIX e o início do corrente, na Rússia. Em meio a elas, revelou-se, em toda a riqueza, o talento de Anton Tchékhov (a partir de 1887-88, prosador menos fecundo mas cada vez mais concentrado e profundo, e também dramaturgo), chegou a termo, em 1910, o caminho literário e terrestre de Lev Tolstói, e surgiu o vulto de literato e ativista de Maksim Górki (1868-1936), notável antes e depois da Revolução de Outubro. A gama das contradições da época ocupou uma plêiade de autores importantes, tais quais Dmítri Mámin-Sibiriak (18521912), Vladímir Koroliénko (1853-1921), chamado de "a consciência da Rússia", Aleksandr Serafimóvitch (1863-1949) e Aleksandr Kuprin (1870-1937).

Aquele período de transição deu algumas das maiores figuras das letras russas da era soviética, como Mikhail Bulgákov (1891-1940), Vladímir Maiakóvski (1893-1930) e Andriéi Platónov (1899-1951), e conheceu muitos talentos originais, que tratariam aspectos do mesmo tema mas os explorariam de maneira inconfundível, fato bem ilustrado por Vladímir Arsiéniev (18721930) e Mikhail Príchvin (1873-1954).

Todo grande escritor, aliás, cria um mundo próprio, projeta as suas alegrias, valores e inquietações nele e ilumina-o com a sua peculiar concepção estética. A simples menção a Iliá Ilf (1893-1937) e Evguiéni Petrov (1902-42), por exemplo, evoca Odessa e outras ensolaradas cidades meridionais dos primeiros tempos do novo regime; o leitor sente-se entre capadócios de todos os tipos e ri-se do tom brejeiro e folgazão da narrativa.

Por motivos editoriais, as notas se encontram no final do texto. 
O nome de cada artista da palavra representa, assim, uma espécie de senha, e esta abre-nos a porta de um mundo de seres, lugares, leis e horizontes singularíssimos.

Serguiéi Essiénin (1895-1925) (1) levanos a espaços largos, para um hausto profundo do ar dos campos e bosques da Rússia Central, ao ritmo de danças de roda primaveris. Trocou o luar e os cânticos agrestes pelo bafio e pela bulha urbanos, mas, nos seus versos, as lembranças da infância nutriam ainda um espírito ansioso por embrenhar-se no mato molhado pela chuva.

Semelhante sensação de chegarmos a um prado florido e recendente a orvalho vem-nos com qualquer referência a um coetâneo seu, que, como ele, não perpassou indiferente por árvores, ervas, rios, animais e pessoas; alguém, enfim, em cujos livros a terra e os seus habitantes receberam um voto de amor: Konstantin Paustóvski.

Não refletiu, pelo menos explicitamente, a atmosfera político-social do país na sua obra, tratando, já então, de problemas hoje momentosos (entre outros, o excessivo praticismo da sociedade industrial, o depauperamento da vida dissociada da arte, do sonho e da natureza, a deterioração das relações humanas e a agressão ao meio ambiente) e logrou traduzir as suas idéias em imagens de fundo significado e grande valor estético.

Exerceu, pelas qualidades pessoais, influência sobre os contemporâneos, principalmente sobre gerações de jovens escritores, a quem não apenas revelou segredos do ofício, como professor do Instituto Literário de Moscou (2), senão também deu, com o exemplo constante, lições de desassombro, dignidade e delicadeza.

Konstantin Gueórguevitch Paustóvski nasceu em Moscou, em 31 de maio de 1892, e passou a meninice e a adolescência em Kíev (3). O pai, Gueórgui Maksímovitch, ferroviário de pendores artísticos, dava atenção ao menino tímido e apegado aos livros, mas viajava muito; os dois irmãos tinham já vida própria; a irmã, semicega e triste, não brincava quase nunca, e a mãe, Maria Grigórievna, não conseguia entender a natureza diferente do filho menor. A escola, com a camaradagem dos condiscípulos e a estima dos mestres, compensava a Paustóvski certa falta de afeto doméstico e foi inteiramente favorável ao seu desenvolvimento (4).

Assim como a figura paterna e a avidez de conhecimentos, importante papel na formação da personalidade literária de Paustóvskidesempenharam as viagens pela Ucrânia, realizadas na infância. Na quinta do avô, ele tinha, além do repertório de aventuras do antigo almocreve e combatente da guerra russo-turca de 1828-29 ("Devo-lhe, em parte, a excessiva impressionabilidade e o romantismo"), as manhãs límpidas do campo, os folguedos no Rio Ros e o populário ucraniano e escutava muito da tradição oral acerca de músicos cegos e andarilhos, e de bandoleiros errantes. As estadas na província davam um sorvo largo de poesia e liberdade ao garoto de cidade grande e marcaram-lhe o espírito observador, ao atuarem sobre a sua inspiração nascente e ao criarem-lhe o gosto pelas letras. O otimismo natural, o olhar apaixonado para o mundo e a tendência a privilegiar sempre o lado bom das coisas, que o velho arrieiro trazia no sangue, encontrariam, no neto, a possibilidade de floração.

Aqueles eram tempos revoltos para a Rússia, engolfada por grave crise econômica e política. Ela representava um país de médio desenvolvimento capitalista, conjugado com resquícios do feudalismo, como a monarquia absoluta, os latifúndios imensos e o trabalho semi-escravo na agricultura. Estendia-se, a todas as regiões, a luta dos operários contra os capitalistas por condições de trabalho dignas e melhor remuneração, a dos camponeses contra os latifundiários pela terra, e a das minorias nacionais pelos direitos civis (5).

Paustóvski, com o divórcio dos genitores, cedo viu-se sozinho na vida. No convívio com pessoas das índoles mais variadas, adquiriu os hábitos, que lhe deram um 
caráter manso e sonhador. Acostumou-se a enxergar o mundo melhor do que este era na verdade, e os seus primeiros escritos não podiam deixar de trazer a marca de um lirismo brumoso, defeso às asperezas da existência, lirismo nutrido não pela experiência, mas pelos estímulos dos livros. A índole contemplativa deu-lhe sentidos muito mais aptos às idealizações da imaginação do que à descrição de fatos, para o que contribuiu poderosamente a leitura de romances de aventura (6).

No verão de 1914, transferiu-se da Universidade São Vladímir, de Kíev, para a Universidade de Moscou. Queria ficar perto da mãe, porque os irmãos mais velhos logo partiriam para a frente - começara a Primeira Guerra Mundial. Ele próprio foi dispensado do serviço militar por causa da miopia, além da sua condição de estudante e filho homem mais moço da família.

$\mathrm{O}$ ano de enfermeiro, passado a pequena distância dos combates, marcou-o profundamente. Ferido por um estilhaço de obuz, foi removido para Moscou e, depois da convalescença, entrou a trabalhar como condutor de bonde. Começou a sua tomada de consciência como cidadão de um país, em que milhões de pessoas morriam de fome, nos anos de catástrofes naturais (secas, fundamentalmente, como as de 1889 , 1891,1892 , 1897 e 1911), e em que se enforcavam ou fuzilavam milhares de outras (7).

As primícias de Paustóvski caracterizaram-se pelo fato de colocar a personagem, parecida a ele nos anseios e nas idéias, em situações e lugares, que ele próprio desejava conhecer. As obras dessa fase constituíam um preito à sua infância, ao fascínio pelo mar e pela vida dos marinheiros, o qual se apoderara dele desde que vira um guarda-marinha em Kíev. A formação de Paustóvski escritor e romântico ocorreu dentro do caudal das buscas ideológicas e estéticas dos anos 20, e a necessidade de levar à letra impressa o seu mundo interior fê-lo tender a usar a fórmula de Aleksandr Grin (8). Paustóvski quis viver as ficções, de que imbuíra o espírito, e escreveu, até o início dos anos 30, contos e romances, em que os leitores não encontravam quase nada que conhecessem e amassem desde a infância; a ação transcorria, quase sempre, longe da Rússia, e viam-se marujos, aven-
O escritor em

uma reserva

florestal

na região de

Riazán, 1966

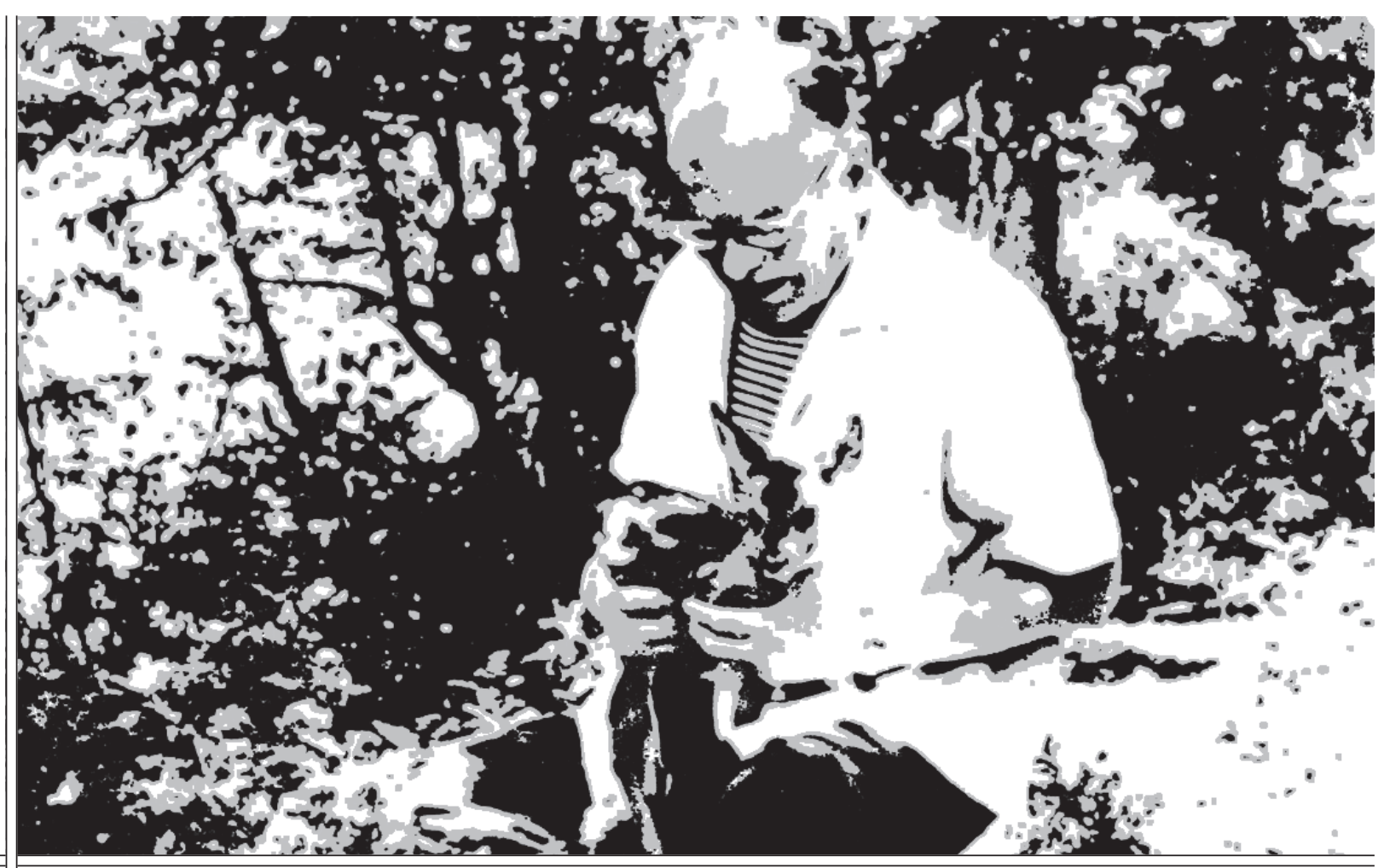


tureiros e quejandos com nomes estrangeiros em situações que não entendiavam mas não comoviam.

Paustóvski intentava, outrossim, a afirmação do indivíduo genial e rebelde, contraposto a um ambiente hostil ou medíocre. Observava-se um imenso abismo entre as impressões do seu quotidiano e a transposição delas para a arte; a suabiografia, marcada por dificuldades de toda natureza e pelo trabalho mal pago - explicador de lições, operário, pescador, enfermeiro, repórter, condutor de bondes, etc., quando não simplesmente desempregado -, contrastava com a existência de personagens livres de todas as agruras do dia-a-dia, egocêntricas e entregues aos tormentos da criação artística.

Gradualmente, a personagem perdeu o padrão superior de humanidade e a dignidade de exceção, a ela conferidos como prêmio por alguma virtude ou esquisitice. A nova atitude com o objeto de representação e com a apreciação deste implicou mudanças na problemática das obras e na sua estrutura. Modificou-se a perspectiva do narrador; o binômio "eu e o mundo" cedeu lugar a “o mundo e eu". No empenho de ligar a inspiração e a imaginação à experiência, encontrou grande ajuda nas muitas viagens, que fazia em serviço (era jornalista desde 1916), ou pela índole irrequieta; iniciava uma literatura, em que registraria as experiências de um espírito sempre desperto e solidário com os semelhantes, dando a elas as cores da fantasia romântica. No convívio com outros literatos e pessoas, com quem tinha afinidades, descobriu, finalmente, o caminho do seu primeiro livro de verdade: Kara-Bugaz (1932) (9).

Pelo beirar da segunda metade dos anos 30 , ele retornaria aos fatores primordiais da sua inspiração: a pátria e a sua expressão visível - a natureza da zona central da Rússia européia e o povo simples. O seu amor a elas encontrou, em cada volta de caminho, em cada clareira e remanso dos riachos da Mechtchora (10), uma ressonância jamais sonhada, afinada com cada vibração da voz das aves. Quando Paustóvski chegou ali, mantinha ainda a sensibilidade de criança e tinha já as qualidades de escritor amadu- recido; a paz contente, rústica, que habitava naqueles sítios, e sobretudo o apelo de uma infinidade de pequenas coisas, que ficavam mais perto dele então, anularam definitivamente a sedução de sereias e serafins, em proveito de potencialidades latentes na sua prosa. Recordar Odessa era ver sol, mar e gente expansiva e atender à lembrança de dias difíceis vividos com muito bom humor; estar na Mechtchora era haurir a energia setentrional, pura, elementar, que desencadeara o seu crescimento artístico (11). À sua obra integrou-se uma realidade camponesa deslumbrada, sim, mas nunca falsa, embora ele não tivesse as unhas cheias de terra ou uma enxada nas mãos. Ele soube sempre enaltecer a melhora das condições de trabalho para os cidadãos comuns, com o acesso à educação e ao mínimo para uma vida decente.

Produziu, a partir de então, uma prosa cheia de fortes emanações da natureza e singelos quadros do dia-a-dia de aldeias e pequenas cidades russas, e apresentava um dom de simpatia, muito apreciável, na intimidade com que descrevia o trabalho e a existência de pessoas modestas e boas. Apesar da pobreza do enredo e dos estorvos causados pela estreiteza da ação, sabia tirar, de fatos corriqueiros, passagens, idéias e sugestões, marcadas por uma sabedoria cheia de simplicidade, que ensinava o gosto das alegrias domésticas, no viver e contentar-se com pouco, e enaltecia virtudes consideradas secundárias, como a paciência, a laboriosidade e a moderação.

Nas obras da sua fase madura, predominou um tipo especial de gente - artistas, artesãos, jardineiros, agrônomos e outros membros da intelliguiéntsia rural, que consideravam, como a sua missão na terra, servir à causa de tornar a vida plena de sentido, multiplicar as belezas do mundo e salvar as suas riquezas. Paustóvski, vivendo na província, defrontava diariamente com os representantes locais do poder central, a face mais imediata e perversa da nomenklatura, e os seus sonhadores ativos foram os seus porta-vozes na luta com os administradores incompetentes e moralmente despreparados, o burocratismo estúpidoe 
tolhedor das pessoas capazes e de iniciativa.

A malevolência da crítica oficial contra ele provinha, basicamente, de ele manterse distante dos cânones do realismo socialista (12) e não dar a mínima importância ao que a Comissão Central do Partido Comunista propugnava para a literatura.

\section{II}

A natureza contribuiu para que a vida de Paustóvski prevalecesse sobre a sua ficção: a geografia exterior impôs-se como a sua geografia interior. O seu renovado lirismo assimilou um material, que antes ele considerava alheio. Entraram nas obras do escritor as pessoas comuns, cuja existência carecia de brilho e se encontrava longe da sua antiga concepção do sublime; tal ocorreu porque o autor era já um homem madurado, curado definitivamente de toda sorte de quimeras. O enfoque realista da época e dos fatos, porém, não impediu as personagens de terem índole sonhadora; o sonho servia-lhes de inspiração criadora, jamais de fuga à realidade.

A relação da natureza com o espírito constitui o aspecto mais fundamental dos contos da fase madura de Paustóvski. A natura aparece sempre como parte integrante do acontecimento descrito, e, assim, quando não ela toda, então uma flor, a tempestade ou o outono, por exemplo, atua como ser vivo. Isso produz um contorno mais do que humanizado - um cenário acrescido de um pouco das personagens, pois o autor impregna animicamente o conjunto de circunstâncias em redor delas.

Paustóvski tem um jeito especial de, ao envolver a ação nos tons límpidos e suaves de algo insólito, criar uma atmosfera poética, a expectativa de uma maravilha, e delinear uma tela de fundo capaz de refletir os sentimentos humanos; dota, ademais, um elemento da natureza de carga conceitual para mostrar uma síntese da situação, a essência do caráter das personagens. Nesse procedimento, conhecido como khudójestvennaia detal' (pormenor artístico), palavras, a que o contexto dá grande poder de sugestão, atuam como música na percepção do leitor, correspondendo a leitmotivs, que sempre voltam em determinadas situações; como se sabe, uma música, quer tirada de um instrumento, quer brotada do meio circundante, se não pode descrever uma coisa, pode muito bem sugeri-la. Em "Neve" e "Amanhecer Chuvoso", Paustóvski usa as palavras "neve" e "chuva", respectivamente, no papel de refrão musical - a primeira retoca uma imagem, a outra acentua um estado de espírito. Põe-se ênfase não na ação, mas na sobreposição de imagens e sons; mais exatamente, criam-se duas justaposições analógicas, neve-pureza e chuva-melancolia, que se repetem de modo regular mas não obsessivo, diminuindo o movimento narrativo. Da mesma forma como os andamentos lentos, na música, se prestam bem ao desejo do compositor de alongar a sinuosidade do pensamento, um instante de satisfação ou de devaneio e o desdobramento da imaginação, ambas prolongam, no tempo, um sentimento que, embora não se analise, é mostrado em vários aspectos, meandros. A alma das personagens revela-se pelo pormenor artístico, fecundo, participante e colaborador da sintaxe lírica da obra.

A estrutura circular de muitos contos de Paustóvski, isto é, o fato de a primeira e a última cenas os emoldurarem com paisagens (13), e, de modo geral, a recorrência constante a estas não enfatizam tanto a dependência do homem em relação à natureza, quanto sublinham a necessidade da complementaridade, que somente ela pode dar à nossa vida. Com o pormenor artístico, uma palavra faz eco à idéia sugerida pelo autor e induz o sentimento do leitor; retira, ademais, o peso das obviedades da linguagem e o substitui pela leveza do elemento poético preciso, que insinua algo e, ao mesmo tempo, diz tudo. Aproximar a natura do mundo interior das personagens não constituía pretexto para o escritor pintála: permitia-lhe apresentar, com mais justeza, as afinidades existentes entre as vibrações do espírito e as do meio circundante. 


\section{III}

Não se lêem os contos de Paustóvski com sofreguidão ou olhos fagulhantes, mas com o sorriso de quem se lembra de algo.

O nosso tempo, com as suas possibilidades de esquecimento coletivo de tudo, e a voragem do desencantamento geral, não preserva a memória; desse modo, a sociedade, em que o olvido se tornou uma instituição, tende mais à substituição das coisas do que à sua conservação ou ao seu resgate; pois bem, na era do trabalho altamente racionalizado e de prodígios da Ciência, a sentimentalidade e a sinceridade da prosa de Paustóvski, com a sua oferta de uma alegria simples e o arejo de conchego doméstico, de respeito à velhice e amor à infância, acenam-nos com o alvitre de tudo que um dia nos recreou o espírito, aguçando-nos a sensibilidade e a imaginação, e necessita manter-se radioso e incólume para colocar um conteúdo mais profundo e mais duradouro nos nossos atos e nas nossas aspirações.

Paustóvski mirava o mundo com os olhos de um romântico, em um anseio de perfeição, e afirmava incansavelmente um fundo perdido das coisas, o sublime no simples. O sentimento representa a componente principal da força, com que a arte desse escritor atua sobre a percepção do leitor; este assiste a certa alvorada do espírito e vê-se diante do altar de um idealismo, que não quer deixar-se degradar.

Os contos de Paustóvski causam estranheza: mais do que uma história desenvolvida, interessam os movimentos da alma, e cabe um papel protagônico ao meio circundante. Vidas, norteadas por um ideal de trabalho, simpatia pelos semelhantes e compaixão pelos outros seres vivos, reafirmam que há mais encanto no mundo do que lhe vemos, e que a aproximação à natureza constitui o encontro da beleza não apenas fora de nós, senão também dentro de nós.

$\mathrm{Na}$ exaltação da natura como fonte eterna de saúde, júbilo e inspiração, Paustóvski cria piamente que o ser humano progrediria moralmente se aprendesse a vê-la e a escutála ("A beleza da terra deverá constituir um dos fatores poderosos da formação do novo homem"). O seu otimismo em relação ao próximo ("Em cada coração, há uma corda, e ela responderá sem falta ao menor chamado do belo") provinha muito mais da sua inclinação natural do que da experiência, mas a idade não o levou nem à lucidez pessimista nem à piedade desdenhosa.

Nenhum escritor tratou com tanto ardor da relação da sociedade com a natureza. Paustóvski expressou as apreensões de pessoas, que encontrou nos últimos trinta, quarenta anos de vida, por aldeias e cidades da União Soviética. Falou corajosamente da incúria dos administradores e dos tecnocratas na exploração dos recursos naturais; não lutou com moinhos de vento apontou problemas e exigiu soluções das autoridades, atacando-lhes a demagogia e os argumentos pretensamente científicos. Ele previu a situação, a que a mentalidade utilitarista, sem compromisso com a felicidade dos seres vivos, levaria o planeta, no limiar do novo milênio...

\section{IV}

O acento invariavelmente emotivo das obras e a maneira sempre terna de, por meio de coisas pequenas, ainda que características e essenciais, declarar a sua afeição aos semelhantes e a alegria de viver no mundo com eles decorriam de uma consciência, que buscava a excelência na simplicidade, e intuía uma poesia presente em tudo.

Paustóvski, contador de histórias marcadas por um lado luminoso, embora não risonho, repudiava a franqueza rude na arte e excluía todas as criaturas torpes do universo da sua ficção; tendia não a analisar fatos, mas a entronizar os seus ideais poéticos - pintava o mundo e as pessoas com as qualidades que lhes queria ver. Por outro lado, a realidade material não perdia nada da sua semelhança essencial ou da sua acessibilidade a todos, porque não sofria uma afirmação vigorosa do $e u$ do escritor; este não buscava a originalidade no traço forte, impressivo. 
Paustóvski foi o artista da serenidade e da suavidade. No plano das personagens, dotava estas de uma personalidade sem desvãos escuros e uma rigidez de princípios, que as movia por caminhos retos, sem desvios e atalhos. Elas não conheciam explosões de energia, como a atitude vigorosa, que muda a sorte de alguém, a façanha, que se paga com a morte; em contrabalanço, colocavam, em cada ação, um pedaço do coração. Ao ambiente de valentia viril, tensão e esforços vitoriosos, o seu criador preferia o mudo encanto do consuetudinário viver, tranqüilo, embora cheio de cuidados, e preenchia a existência delas com os simples, iguais, modestos atos de cada dia, inspirados pelo sentido do dever e executados sem ênfase, teatralidade ou afetação.

No plano cromático, preferia os meiostons das aquarelas e as cores cambiantes; convertia cenas comuns em instantâneos cheios de graça, na sua singeleza, e comoventes, no seu frescor límpidoe comunicativo. Para ele, averso à cópia fotográfica dos acontecimentos, ao lado destes, "tal qual luz complementar, embora suave, brilhou sempre uma leve fantasia romântica".

Paustóvski queria ressuscitar o mundo no encanto e no frescor primevos, e cultuava a infância, a adolescência sonhadora e o amor, porque eles constituíam representações do alvorecer. Assim, como emblema da leveza dos seus contos, pode escolherse o arco-íris, associado sempre a descobrimento, mistério, milagre, renascimento.

"Largo arco-íris sobranceava a floresta; ao fundo, além de um lago, caía uma chuva leve. $O$ arco celeste parecia [...] a entrada de países secretos, misteriosos, em que [...] gritavam grous no amanhecer" na cena final do conto "O Velho Barco" ("Stáry tchólny", 1939).

Lermos Paustóvski, na idade adulta, é revermo-nos diante desse arco-íris, além do qual os rios se nos afiguravam mais largos e mais profundos, o Sol brilhava com mais força, os bosques exalavam mais magia, e era mais aliciadora a voz da distância; é relembrarmos valores, que produziram ímpetos generosos em nós.

Os contos de Paustóvski contêm um apelo a conservarmos a crença em coisas boas e o dom de maravilhar-nos, pelo que outrora fomos iguais às suas personagens pessoas capazes de assombrar-se com o reflexo do céu em poças de água e o germinar de uma semente no meio das pedras de uma linha de trem, e de agradecer ao pardal o ninho sob o beiral, ao cão e à árvore a companhia, e àágua o poema da vida, repartido com a terra; enfim, pessoas que contemplam o mundo com um olhar puro e honesto e esperam algo magnífico dos outros.

\section{DOIS CONTOS DE PAUSTÓVSKI} $(14)$

\section{Neve $(15)$}

O velho Potápov faleceu um mês depois de Tatiana Petrovna haver-se instalado na casa dele. Ela permaneceu ali, com a filha Vária (16) e a ama-seca.

A morada, de apenas três aposentos, ficava sobre um outeiro, sobranceira a um rio do Norte, à saída de uma cidadezinha. Atrás dela, além do jardim desfolhado, branquejava um bosque de bétulas. Voando sobre os cimos nus das árvores, bandos de gralhas crocitavam da alvorada ao anoitecer, como se a chamarem o tempo chuvoso e sombrio.

Tatiana Petrovna, que era de Moscou, por longo tempo não conseguiu acostumarse à cidadezinha deserta, às suas casinhas, aos portões rangentes e às noites silenciosas, quando se ouvia o crepitar do fogo na lamparina de querosene.

“Como fui tola! - pensava. - Por que parti, por que deixei o teatro, os amigos?! Devia haver levado Vária para a casa da ama, em Púchkino (17) - ali, não ocorriam bombardeios -, mas eu própria devia haver ficado em Moscou. Como fui tola!"

Regressar, porém, era já impossível. Ela decidiu, então, apresentar-se nos muitos hospitais militares locais, e sossegou. Começou até a gostar do lugar, sobretudo quando chegou o inverno, cobrindo-o de 
neve. Os dias tornaram-se suaves, cinzentos. O rio demorou muito a gelar; da sua água verde emanava um véu de vapor.

Tatiana Petrovna habituou-se também à casa alheia. Habituou-se ao piano desafinado, às fotografias amarelecidas, de pesados encouraçados da defesa costeira, que ornavam as paredes. O velho Potápov fora mecânico de bordo. Sobre a sua escrivaninha, coberta de feltro verde desbotado, havia um modelo do cruzador "Gromoboi", em que servira. Não permitiam a Vária tocá-lo. A bem dizer, não lhe permitiam bulir em nada.

Tatiana Petrovna sabia que Potápov deixara um filho, na frota do Mar Negro. Havia um retrato seu ao lado da réplica do navio. Às vezes, ela o pegava, fitava-lhe os olhos e, com as finas sobrancelhas franzidas, perdia-se em pensamentos. Parecia-lhe sempre que encontrara já aquele jovem oficial, mas havia muito tempo, ainda antes do seu malogrado casamento. Mas onde? Quando?

O marinheiro mirava-a com olhos serenos, um tanto zombeteiros, como se perguntasse: "Será que não consegue lembrarse de onde nos encontramos?"

- Não, não me lembro - respondia ela, em voz baixa.

- Mamãe, com quem falas? - gritava Vária do aposento contíguo.

- Com o piano - respondia ela, e ria.

No inverno, começaram a chegar cartas para o falecido, sobrescritas sempre pela mesma mão. Tatiana Petrovna empilhava-as sobre a escrivaninha. Certa vez, despertou tarde da noite. A neve irradiava uma luz pálida sobre a vidraça. No sofá, ressonava Arkhip, o gato cinzento do antigo dono da casa.

Ela vestiu o roupão, foi ao gabinete de Potápov e deixou-se ficar um momento de pé, junto à janela. Um pássaro despegou-se silenciosamente de uma árvore, sacudindo a neve do ramo. Ela caiu lentamente, fininha, e polvilhou os vidros.

Tatiana Petrovna acendeu uma vela sobre a mesa, sentou-se em uma poltrona e olhou longamente para a lingüeta de fogo, que sequer estremecia. Depois, pegou uma das cartas, abriu o sobrescrito e, após olhar para trás, para a porta, começou a ler.
“Meu querido velho, faz já um mês, que estou no hospital. O ferimento não é muito grave. Até está já a cicatrizar. Por favor, não fiques preocupado e não fumes um cigarro atrás do outro. Eu te imploro!

Lembro-me de ti freqüentemente, papai-continuou Tatiana Petrovna a ler,$- e$ também de casa, da nossa cidadezinha. Tudo isso está terrivelmente longe, como se do outro lado do mundo. Fecho os olhos $e$, então, vejo-me abrir o portão, entrar no jardim. É inverno, há neve, mas está limpo o caminho do velho caramanchão da borda do barranco, e as moitas de lilás estão brancas de geada. Em casa, crepita ofogo do forno, e sente-se o cheiro do fumo de achas de bétula. Opianofoi afinado, finalmente, e tu colocaste, nos castiçais, as velas amarelas torcidas, aquelas que eu trouxe de Leningrado. E, sobre o piano, estão as mesmas partituras: a abertura de 'A dama de espadas' (18), a romança 'Para as margens da pátria longínqua...' (19). Funciona ainda a campainha da porta? Eu acabei não tendo tempo de consertá-la. Será que verei outra vez tudo isso? Será que outra vez me lavarei com um jarro de águado nosso poço, ao chegarde viagem? Lembras-te? Ah, se soubesses como passei a gostar disso tudo daqui de longe! Não te admires, eu falo com toda a seriedade: eu recordei essas coisas nos momentos mais terríveis da guerra. Eu sabia que estava a defender não só o nosso país inteiro, senão também esse seu cantinho-o mais caro de todos a mim -, a ti, o nosso jardim, os meninos de gaforinha, os bosques de bétulas do outro lado do rio e o gato Arkhip. Por favor, não rias, nem abanes com a cabeça.

Pode ser que, quando receber alta do hospital, me autorizem a passar alguns dias em casa. Não sei. Mas é melhor não esperares".

Tatiana Petrovna permaneceu longo tempo sentada junto à mesa, a olhar para fora, com os olhos muito abertos; no azul profundo, principiava o amanhecer. Pensava em um desconhecido poder chegar de um dia para o outro e em quão penoso lhe seria encontrar pessoas estranhas na casa e ver tudo bem diferente do que desejava. 


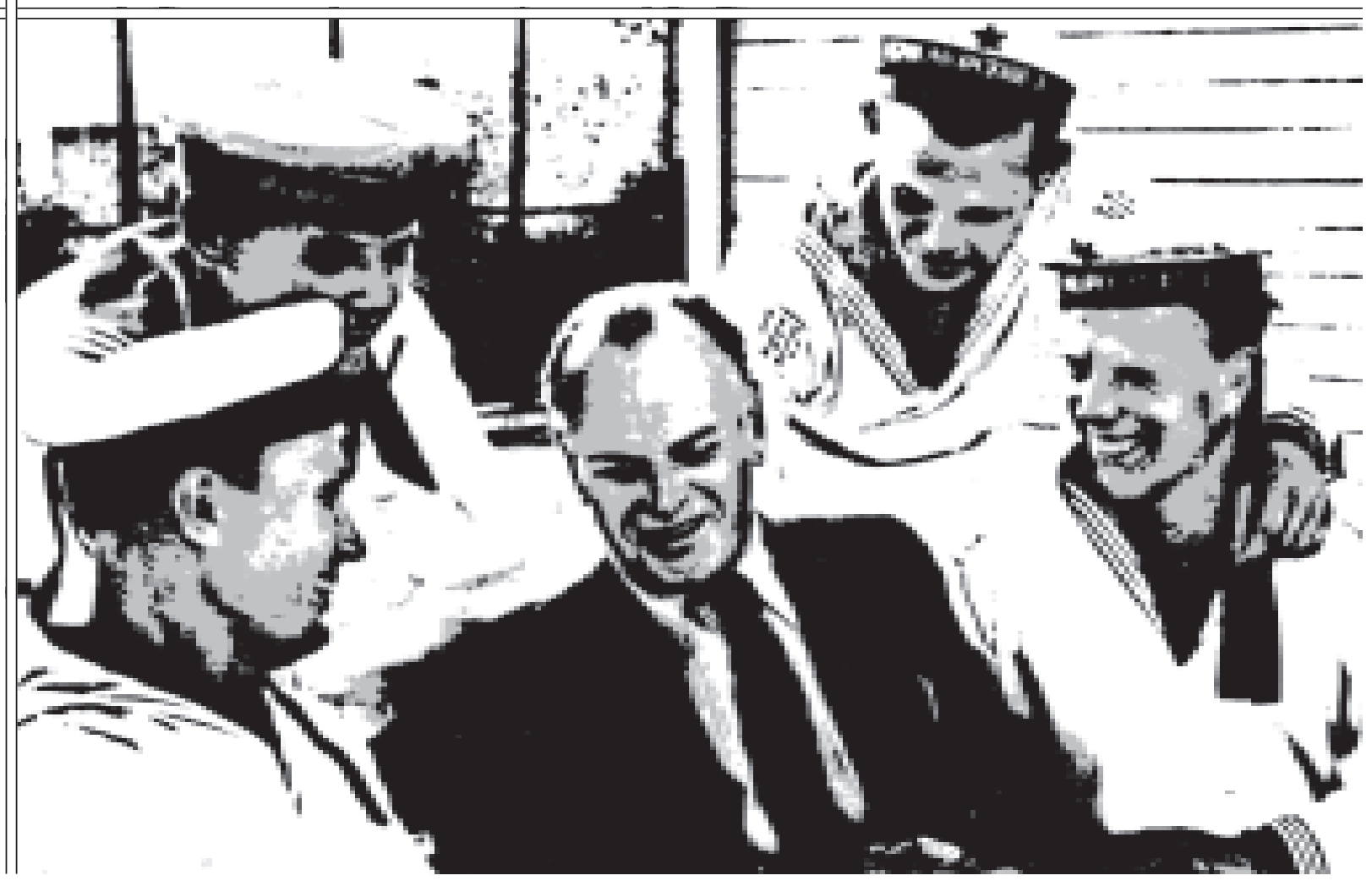

De manhã, mandou Vária pegar uma pá e limpar o caminho do caramanchão. Ele estava já completamente vetusto. As suas colunas de madeira, cobertas de líquens, haviam ficado brancas. Ela própria consertou a sineta da porta, que tinha uma inscrição engraçada: “Junto à porta éo meu lugar - mais alegre fazei-me soar!" Ela tocou a sineta, e esta retiniu com som argentino. $\mathrm{O}$ gato Arkhip agitou as orelhas, irritado, ofendeu-se e saiu da ante-sala: o tilintar alegre, pelo visto, parecia-lhe insolente.

À tarde, com os olhos escurecidos pela comoção, Tatiana Petrovna trouxe um tcheco russificado, que consertava fogareiros a querosene, bonecas e harmônicas e afinava pianos. O seu sobrenome era muito cômico: Niévidal' (20). Ao terminar o serviço, ele disse que o piano era antigo mas muito bom. Tatiana Petrovna bem sabia já disso.

Quando o velho se foi, ela deu uma espiadela discreta em todas as gavetas da escrivaninha e encontrou um maço de grossas velas torcidas. Colocou-as no castiçal, sobre o piano. À noite, acendeu-as, sentouse ao teclado, e a casa encheu-se de acordes.
Quando cessou de tocar e apagou as velas, nos aposentos, sentiu-se um cheiro adocicado de fumaça, como o exalado por um pinheirinho na festa de Ano Novo.

Vária não se conteve.

- Por que mexes nas coisas dos outros? Eu não posso, mas tu podes! A sineta, as velas, o piano, mexes em tudo. E também colocaste partituras dos outros sobre o piano.

- Porque eu sou adulta - respondeulhe a mãe.

A menina olhou para ela, desconfiada e de cenho franzido. Naquele momento, Tatiana Petrovna parecia tudo, menos uma pessoa adulta. Ela como que resplandecia, e lembrava a moça de cabelos dourados, que perdera um sapatinho de cristal em um palácio. Ela própria contara a história dessa rapariga a Vária.

Ainda no trem, o tenente Potápov calculou que não poderia passar mais de um dia em casa. A licença era muito breve, e a
Com

marinheiros da

Frota do Mar

Negro.

Sebastópol, 1957 
viagem tomar-lhe-ia quase todo o tempo.

Desembarcou na cidadezinha à tarde. Ainda na estação, soube que o pai morrera um mês antes e que a casa estava ocupada por uma cantora de Moscou, com a filha.

- Uma refugiada - disse-lhe o chefe da estação.

Potápov mantinha-se calado e olhava para a janela; alguns passageiros, de roupas acolchoadas e botas de feltro, corriam com chaleiras, em busca de água para o chá. Ele sentia tontura.

- O seu pai era um homem de bom coração. É pena que ele não tenha podido revê-lo.

- Quando passará o trem de volta?

- Às cinco horas da manhã, - respondeu o chefe e, após um momento de silêncio, acrescentou: - Até lá, fique em minha casa. A minha velha lhe fará um chá e dará algo de comer. Não tem por que ir à sua.

— Obrigado-respondeu Potápov e saiu.

O outro seguiu-o um instante com os olhos e abanou com a cabeça.

Potápov atravessou a cidadezinha, rumo ao rio. Sobre este, estendia-se um céu cinzento-azulado. Entre ele e a terra, voava uma nevezinha esparsa, em linha oblíqua. Pelo caminho, onde excremento de cavalo se misturava à neve, vagavam gralhas. Escurecia. Da outra margem, da floresta, soprava o vento, marejando os olhos de lágrimas.

"Pois então! - disse ele. - Cheguei tarde. E agora é como se tudo isto fosse estranho para mim: esta cidadezinha, o rio, a casa". Voltou-se, olhou para o outeiro, ao fundo da cidade. Ali, avistava-se o jardim, coberto de escarcha, e negrejava a casa. Um rolo de fumo subia-se da chaminé. O vento levava-o para o bosque de bétulas.

Potápov seguiu lentamente naquela direção. Estava decidido a não entrar em casa, mas apenas passar em frente dela, talvez dar uma olhadela ao jardim e ficar um momento no velho caramanchão. O pensamento de que ali se encontravam pessoas estranhas, indiferentes, era-lhe insuportável. Seria melhor não ver nada, não exacerbar a dor do coração, partir, não ver nada!

"Pois é - pensou - , a cada dia amadurecemos mais e olhamos em redor com mais gravidade".

Aproximou-se da casa no crepúsculo. Abriu o portão com cuidado, mas este, ainda assim, rangeu. O jardim como que estremeceu. Uma porção de neve desprendeuse dos ramos e farfalhou. Potápov olhou em torno de si. Ao caramanchão levava um caminho aberto a pá na neve. Foi para ali e pousou as mãos sobre a velha balaustrada. Ao longe, além da floresta, o céu tingia-se de turvo arrebol: era a Lua, provavelmente, que se alçava atrás das nuvens. Potápov tirou o quepe, passou a mão pelos cabelos. Reinava grande quietude; apenas embaixo, ao pé do barranco, algumas mulheres faziam tinir os baldes vazios, indo buscar água a um buraco aberto na crosta gelada do rio.

Ele apoiou os cotovelos na balaustrada e disse baixinho:

"Como pôde ser isto?"

Alguém tocou-lhe delicadamente o ombro. Ele se voltou. Era uma mulher jovem, de rosto pálido e grave, com um xale de lã sobre a cabeça. Ela o mirava em silêncio, com os olhos escuros atentos. Nos seus cílios e faces, derretia-se um negalho de neve, caído dos ramos, decerto.

- Ponha o quepe - disse ela, em voz baixa-senão, poderá constipar-se. Vamos para dentro. Não precisa ficar aqui fora.

Potápov não disse nada. Ela o segurou pela manga do capote e conduziu-o. Ao chegarem ao alpendre, ele parou. Um espasmo apertava-lhe a garganta, fazendo-o respirar com dificuldade. Ela disse, em voz baixa, como antes:

- Isso não é nada. E, por favor, não se acanhe. Isso passará logo.

Ela bateu os pés para sacudir a neve das galochas. No mesmo instante, como em resposta, ressoou a sineta da porta. Potávov suspirou fundo e tomou alento.

Entrou perturbado, a murmurar qualquer coisa, tirou o capote na ante-sala, sentiu o cheiro suave do fumo de achas de bétula e viu Arkhip. O gato estava sentado no sofá e bocejava. De pé, ao seu lado, uma menina de trancinhas olhava alegre para Potápov, não para o seu rosto, mas para os galões dourados da manga da túnica.

- Vamos! - disse Tatiana Petrovna e 
levou-o para a cozinha.

Ali, havia água fria do poço em um jarro e, pendurada ao seu lado, uma toalha de linho, bordada de folhas de carvalho, que Potápov imediatamente reconheceu.

Tatiana Petrovna saiu. A menina trouxe sabonete e ficou a olhar para Potápov; ele tirou a túnica e começou a lavar-se. A sua perturbação ainda não passara.

— Quem é a tua mamãe? - perguntou e corou.

Fez a pergunta apenas por dizer alguma coisa.

- Ela pensa que é adulta - murmuroulhe Vária, em tom de segredo. - Mas não é adulta nem um pouquinho. Ela é uma menina pior do que eu.

\section{- Por quê?}

Vária, porém, não lhe respondeu; riu e saiu, correndo, da cozinha.

O tempo todo, Potápov não conseguiu livrar-se da estranha sensação de estar a viver um sonho leve mas muito consistente. Todas as coisas estavam como queria vê-las. As mesmas partituras repousavam sobre o piano, as mesmas velas retorcidas estavam acesas, a estalejar, e iluminavamo pequeno gabinete do pai. Até as suas missivas do hospital estavam sobre a escrivaninha, sob a mesma velha bússola, sob a qual o pai costumava colocar cartas.

Após o chá, Tatiana Petrovna levou-o ao cemitério, além do bosque de bétulas. A Lua ia já alta, enevoada. À sua luz, as árvores brilhavam, deitando tênues sombras sobre a neve.

Depois, tarde da noite, ela, sentada ao piano, a correr suavemente os dedos pelo teclado, voltou-se para Potápov e disse:

- Tenho sempre a impressão de que já o vi em algum lugar.

- Pode ser.

Olhou para ela. A luz das velas incidia nela de lado, iluminando-lhe metade do rosto. Ele se levantou, percorreu o aposento de uma extremidade à outra e parou.

- Não, não consigo lembrar-me - disse, com voz surda.

Ela se voltou, olhou assustada para ele mas não the disse nada.

Potápov foi acomodado no gabinete do pai, mas não conseguiu adormecer. Cada minuto, ali, parecia-lhe precioso, e ele não queria perdê-lo.

Deitado, escutava os passos furtivos de Arkhip, o tinido da pêndula, o cochichar de Tatiana Petrovna com a ama. Depois, as vozes calaram-se, e a velha recolheu-se, mas, sob a porta, não se extinguiu a réstia de luz. Ouvia-se um farfalhar de páginas Tatiana Petrovna lia. Ele compreendeu, então, que ela não se deitara para acordálo. Sentiu vontade de dizer-lhe que também não dormia, mas não se decidiu a chamá-la.

Às quatro horas, ela abriu silenciosamente a porta e chamou-o. Ele se mexeu sobre o sofá.

- É hora de levantar-se. Sinto muito ter de acordá-lo!

Ela o acompanhou à estação, pela cidadezinha noturna. Despediram-se após o segundo sinal da sineta. Ela lhe estendeu ambas as mãos e disse-lhe:

- Escreva. Nós somos quase parentes, agora. Não é verdade?

Ele não respondeu, apenas acenou com a cabeça.

Dias depois, Tatiana Petrovna recebeu uma carta de Potápov, escrita ainda no trem.

“Eu me lembrei, claro, do lugar, onde nós nos encontráramos - escrevia ele -, mas não quis falar-lhe sobre isso aí, em casa. Recorda-se da Criméia, em mil novecentos e vinte e sete? Era outono. Os plátanos do parque de Livádia. O céu cada vez mais escuro, o mar pálido. Eu seguia pelo caminho de Oreanda. À beira dele, em um banco, estava sentada uma moça. Ela devia ter uns dezesseis anos. Quando me viu, levantou-se e veio na minha direção. Quando perpassava por mim, olhei para ela. Passou por mim rapidamente, a passo leve, com um livro aberto em uma das mãos. Parei e segui-a longamente com o olhar. Era a senhora. Não posso estar enganado. Eu olhava para ela e senti, então, que junto de mim passara a mulher, que tanto poderia destruir a minha vida, como dar-me uma felicidade imensa. Compreendi que poderia amar aquela mulher até à completa renúncia a mim próprio. Já então eu sabia 
que deveria reencontrá-la, custasse o que custasse. Assim pensava eu, naquela época, mas, apesar de tudo, não me movi do lugar. Por que, não sei. Desde então, passei a gostar da Criméia e daquele caminho, onde a vi por um momento e perdi para sempre. A vida, porém, foi generosa comigo, e eu a reencontrei. Se tudo terminar bem e a minha vida lhe for necessária, ela, certamente, será sua. Ah, sim, encontrei aberta uma carta minha, sobre a mesa de papai. Compreendi tudo e só posso agradecer-lhe daqui, de longe".

Tatiana Petrovna pôs de lado a carta, olhou para fora, para o jardim nevado, com os olhos enevoados.

- Eu nunca estive na Criméia! Nunca! Mas pode lá isso ter alguma importância agora? Para que desenganar a ele? E a mim também?!

Começou a rir e cobriu os olhos com a palma da mão. Além da janela, ardia um pôr-do-sol opaco, que não conseguia extinguir-se.

\section{A cesta de pinhas de abeto}

O compositor Edvard Grieg (22) estava a passar ooutono nos bosques, pertode Bergen.

Todas as florestas são belas, com o ar de cogumelos e o farfalhar das folhas. Mas as dos montes costeiros possuem um encanto especial. Nelas, ouve-se a ressaca. A viração abruma-as constantemente, e, com a abundância de umidade, o musgo cresce exuberante. Ele pende dos ramos ao solo, como madeixas verdes.

Nas florestas das montanhas, ademais, qual pássaro zombeteiro, mora um eco alegre. Ele está sempre à espera de um som, para apanhálo e atirá-lo de penhasco em penhasco.

Certa vez, Grieg encontrou uma menina de trancinhas, filha de um guarda-bosques. Ela carregava uma cesta e apanhava pinhas de abeto. Se fosse possível juntar todo o ouro e todo o cobre do mundo e deles forjar milhares e milhares de finíssimas folhas, elas representariam apenas uma parte ínfima das vestes outonais. Também pareceriam toscas em comparação às verdadeiras, principalmente às do álamo tremedor, que, como se sabe, vibram até a um silvo de pássaro.

- Como te chamas, menina?

- Dágni Pédersen - respondeu ela, a meia voz. Falou baixinho por embaraço, não por medo. Não podia assustar-se, pois os olhos de Grieg sorriam.

- Que lástima! Não carrego nada que te possa dar de presente. Não tenho nenhuma boneca, fita ou coelhinho de veludo nos bolsos.

- Eu tenho uma boneca velha, que foi da minha mãe - disse a menina. - Antes, ela fechava os olhos. Assim, olhe!

Ela fechou os olhos devagarinho. Quando os reabriu, Grieg notou que os seus olhos eram esverdeados e que a folhagem coriscava neles.

- Agora, ela dorme de olhos abertos acrescentou Dágni, com tristeza. - As pessoas velhas dormem mal. O vovô também se lamuria a noite toda.

- Escuta, Dágni, já sei. Dar-te-ei uma coisa bem interessante. Mas não agora, daqui a uns dez anos.

Ela ergueu os braços.

- Oh, quanto tempo!

- Eu tenho ainda de fazê-la.

- E que é?

- Um dia o saberás.

- Mas será que não consegue fazer mais do que cinco ou seis brinquedos, em toda a sua vida? - perguntou Dágni, severa.

Grieg atrapalhou-se.

- Não, não é bem assim - retorquiulhe, sem convicção. - Talvez até a faça em poucos dias. Mas essas coisas, normalmente, não se dão a crianças. Os meus presentes são para gente grande.

- Eu não a farei em pedaços - disse Dágni, em tom suplicante, e puxou Grieg pela manga. - Eu não a quebrarei. Verá! $\mathrm{O}$ vovô tem um barquinho de brinquedo, de vidro. Pois eu limpo o pó dele e nunca tirei nem o menor caquinho.

“Eh, essa Dágni deixou-me completamente atrapalhado" - pensou Grieg, com enfado, e disse o que os adultos sempre dizem, quando se vêem em situação incô- 
moda perante crianças:

- És pequena e muitas coisas ainda não consegues entender. Aprende a ter paciência. Agora, dá cá isso. É muito pesado para ti. Eu te acompanharei e nós falaremos de outra coisa.

Dágni suspirou e passou-lhe a cesta. Ela estava realmente pesada. As pinhas de abeto contêm muita seiva, e por isso pesam muito mais do que as de pinheiro.

Quando a casa do guarda-bosques apareceu entre as árvores, Grieg disse:

- Bem, daqui irás numa corridinha, sem mim, Dágni Pédersen. Na Noruega, há muitas meninas com esse nome e sobrenome. Como se chama o teu pai?

- Haguerup - respondeu Dágni e, com a testa franzida, perguntou: - Será que não quer entrar um pouco? Nós temos uma toalha de mesa bordada, um gato amarelo e um barquinho de vidro. Vovô deixará pegálo na mão.

- Obrigado. Agora, não tenho tempo. Adeus, Dágni.

Grieg afagou-lhe o cabelo e foi em direção ao mar. A menina ficou a olhá-lo, carrancuda. Segurava a cesta meio de lado, e dela caíam algumas pinhas.

“Comporei uma música-decidiu Grieg. - No frontispício, mandarei porem assim: “A Dágni Pédersen, filha do guarda-bosques Haguerup Pédersen, quando completar dezoito anos".

Em Bergen, tudo seguia como antes.

Havia já muito, Grieg retirara de casa tudo o que pudesse abafar os sons: tapetes, reposteiros e móveis estofados. Ficara só um sofá velho. Sobre ele, podia assentar-se até uma dezena de visitantes, e, por isso, o compositor não se decidia a desfazer-se dele.

Os amigos diziam que a sua casa parecia a morada de um lenhador. O único adorno era um piano. Qualquer pessoa dotada de imaginação ouviria coisas mágicas, entre as suas paredes: do murmúrio do Mar do Norte, que rolava as suas ondas das trevas, e do vento, que assobia a sua saga bravia sobre elas, até a canção de uma menina para a sua boneca de pano.

O piano podia cantar sobre tudo: o impulso do espírito humano para o sublime, e o amor. As teclas brancas e negras, escapulindo sob os dedos vigorosos de Grieg, expressavam tristeza, riam, troavam, furiosas como uma tempestade, e emudeciam de repente. Então, no silêncio, por muito tempo, soava ainda uma corda pequenina, como se chorasse Cinderela ofendida pelas irmãs.

Grieg recostava-se sobre o sofá e punha-se à escuta desse som, até ele extinguir-se na cozinha, onde havia muito morava um grilo.

Podia ouvir-se o pingar da água de uma torneira, a marcar os segundos com a precisão de um metrônomo. Os pingos repetiam que o tempo não esperava e que era preciso apressar-se para conseguir fazer tudo o que se tinha em mente.

Grieg gastou mais de uma semana para escrever a música para Dágni Pédersen.

Começara o inverno. O nevoeiro envolveu densamente a cidade. Navios enferrujados chegavam de vários países, dormitavam junto ao cais de madeira, de quando em quando resfolegando vapor, baixinho.

Logo vieram as nevadas. Pela janela, Grieg via a neve voar obliquamente e prender-se à coruta das árvores.

Naturalmente, é impossível transmitir música por meio de palavras, por mais rico que seja o nosso idioma.

Grieg compunha sobre o encanto mais profundo da juventude e da felicidade.

Entrementes, via correr-lhe ao encontro, ofegante de alegria, uma moça de olhos verdes brilhantes. Ela o abraçava e apertava as faces às dele, brancas da barba por fazer. "Obrigada!" - dizia, ela própria ainda sem saber por que lhe agradecia.

“Tu és como o Sol - dizia ele. - Como o meigo vento da madrugada. Uma flor branca desabrochou no teu coração e encheu todo o teu ser com a fragrância da primavera. Eu vi a vida. Não importa o que te disserem sobre ela, crê sempre que é admirável e bela. Sou um velho, mas consagrei toda a minha vida, todo o meu trabalho e o meu talento à juventude. Consagrei 
tudo, definitivamente. Por isso, eu talvez seja até mais feliz do que tu, Dágni.

Tu és a noite branca (23) com a sua luz misteriosa. Tu és a felicidade. Tu és o brilho da alvorada. À tua voz, o coração treme.

Abençoado seja tudo o que te rodeia, o que te toca e o que tocas, o que te alegra e faz pensar...".

Assim pensava Grieg, e tocava sobre tudo em que pensava. Suspeitava que alguém o escutava furtivamente. Até adivinhava quem podia ser. Eram os chapins (24) pousados em uma árvore, os marinheiros pândegos do porto, a lavadeira do prédio vizinho, o grilo, a neve e Cinderela com um vestido passejado.

Cada um o escutava a seu modo.

Os chapins estavam inquietos. Por mais que se agitassem, a sua tagarelice não conseguia sobrepor-se ao piano.

Os marinheiros folgazões estavam sentados nos degraus da escada, à entrada do prédio, atentos à música, e choravam. A lavadeira aprumara o corpo. O grilo, volta e meia, saía de uma rachadura da chaminé e lançava uma olhadela a uma frincha atrás de Grieg.

A neve detinha a queda e pairava no ar, para escutar o tilintar, que fluía aos borbotões da casa.

Cinderela olhava para o chão, a sorrir. Junto aos seus pés descalços, estavam dois sapatinhos de cristal. Estremeciam, batendo um no outro, em resposta aos acordes vindos do quarto de Grieg.

Ele apreciava esses ouvintes mais do que os freqüentadores elegantes e corteses dos concertos.

\section{Na outra}

página,

Paustóvski

enfermeiro

durante

a Primeira

Guerra

Mundial, 1915
Aos dezoito anos, Dágniconcluiu a escola.

Por esse motivo, o pai enviou-a para Cristiânia, para que passasse um tempo com Magda, irmã dele. O guarda-bosques decidira que a menina (ele a julgava ainda criança, embora fosse já uma moça esbelta, com pesadas tranças louras) devia ver como era o mundo, como viviam as pessoas, e divertir-se um pouco.

Quem sabia o que o futuro reservava para Dágni? Talvez um marido honrado e amoroso mas aborrecido e um tanto avaro? Ou o trabalho de vendedora em uma mercearia de aldeia? Ou um serviço qualquer em uma das muitas companhias de navegação de Bergen?

Magda era costureira em um teatro. Ali, também, como cabeleireiro, trabalhava Nils, seu marido.

Eles moravam em um quartinho, sob o telhado do teatro. Dali, via-se o golfo, multicor das bandeiras das embarcações, e o monumento a Ibsen.

Pela janela, o dia inteiro se ouviam as sirenes dos navios. Nils já estudara tanto as suas vozes, que dizia poder reconhecer, sem medo de errar, de quem era o apito: se do "Noderguei", de Copenhague, se do "Cantor Escocês", de Glasgow, ou do "Joana D'Arc", de Bordéus.

No aposento, havia uma porção de coisas do teatro: brocado, sedas, fitas, rendas, chapéus de feltro antigos, com penas negras de avestruz, xales ciganos, perucas brancas, botas de montar com esporas de cobre, espadas, leques e sapatos prateados e gastos nas dobras. Era necessário pregar, consertar, limpar e passar tudo aquilo.

Das paredes pendiam gravuras recortadas de livros: cavaleiros do tempo de Ludovico XIV, beldades de crinolina, camponesas russas, marinheiros e víquingues com coroas de ramos de carvalho na cabeça.

Subia-se ao quarto por uma escada íngreme. Ali, havia sempre cheiro de tinta e de laca de douradura.

Dágni ia ao teatro assiduamente. Era um entretenimento fascinante. Porém, quando ela se deitava, após os espetáculos, demorava em adormecer e, às vezes, até chorava.

Magda, assustada, tranqüilizava-a. Dizia-lhe que não se devia crer cegamente no que acontecia no palco. Já Nils, por causa disso, chamou "galinha choca" à sobrinha e disse que, pelo contrário, no teatro, é preciso acreditar em tudo. Senão, as pessoas não precisariam de teatro nenhum. E Dágni acreditava. 
Mas, apesar de tudo, Magda insistiu com ela e convenceu-a a ir a um concerto, para variar.

Nils não se opunha à idéia. “A Música - dizia - é o espelho do gênio”.

Gostava de expressar-se de modo empolado e nebuloso. De Dágni, dizia que parecia o primeiro acorde de uma abertura. E a esposa, segundo suas palavras, tinha um poder de feiticeira sobre as pessoas. Esse se manifestava nas roupas, que fazia para o teatro. E quem não sabe que uma pessoa muda completamente, ao vestir uma roupa nova? Isso quer dizer que o mesmo ator, ontem, foi um assassino infame, hoje, tornou-se um amante ardoroso, amanhã, será o bobo de uma corte, e, depois de amanhã, o herói de todo um povo.

- Dágni - gritava Magda, em tais casos -, tapa os ouvidos e não escutes a sua tagarelice absurda! Ele próprio não entende o que diz, esse filósofo de sótão!

Junho estava quente. Era a época das noites brancas. Realizavam-se concertos a céu aberto, no parque municipal.

Dágni foi a um com os tios. Queria vestir o seu único vestido branco. Mas Nils disse que uma moça bonita deveria estar vestida de um modo que a fizesse sobressair entre as outras pessoas. Com o longo discurso sob esse pretexto, queria dizer, em suma, que, nas noites brancas, ela devia vestir-se de negro, e, nas escuras, de branco.

Vencer Nils em uma discussão era impossível, e Dágni pôs um vestido de veludo macio e assedado. A tia tirara-o do guardaroupa do teatro.

Ao vê-la, Magda concordou com Nils: nada acentuava mais a palidez grave do rosto de Dágni e as suas longas tranças com reflexo de ouro envelhecido do que aquele veludo misterioso.

- Olha, Magda - disse Nils, baixinho -, Dágni está tão bonita, que parece estar indo ao seu primeiro encontro de amor.

- Pois, precisamente! - respondeu Magda. - Não sei por que, mas eu não vi nenhum bonitão irresistível perto de mim, quando foste ao nosso primeiro encontro. Não passas de um tagarela. - E beijou-lhe a cabeça.

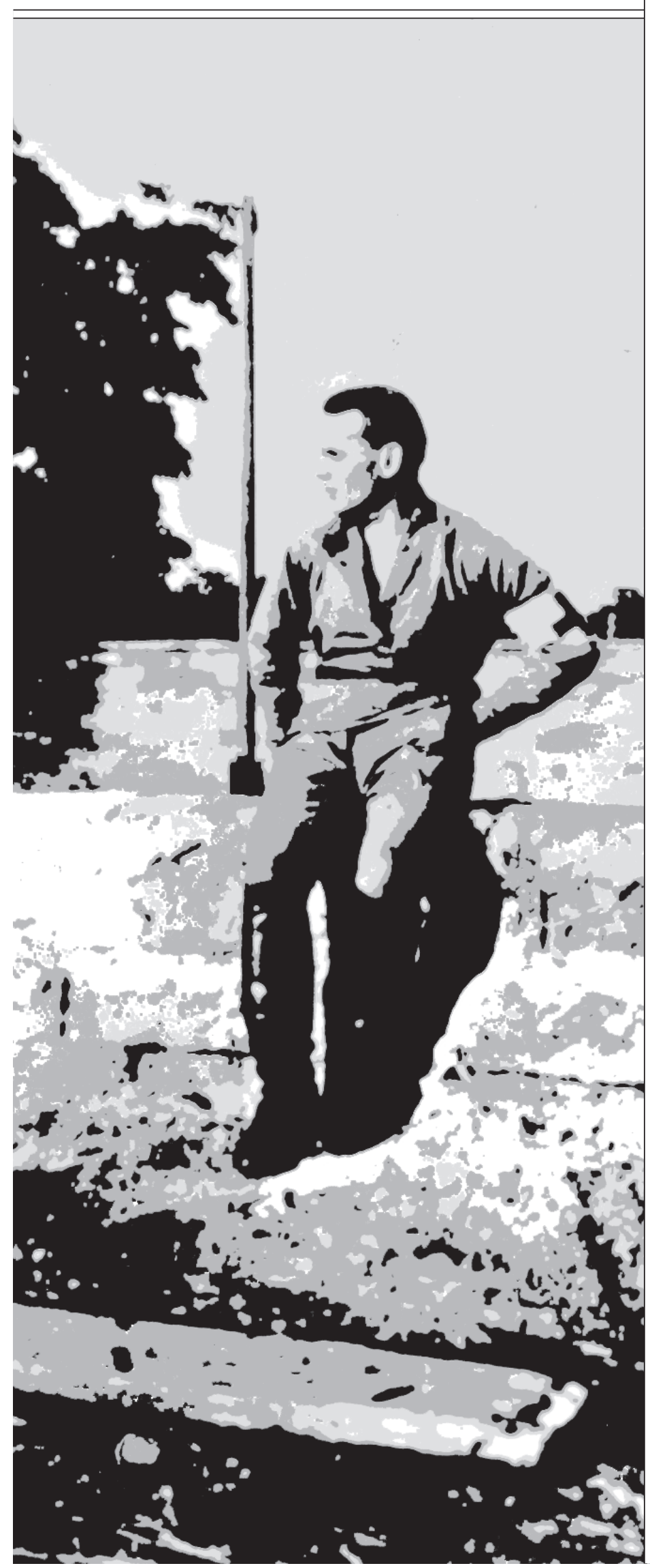


O concerto começou após o disparo habitual do canhão do porto. O tiro assinalava o pôr-do-sol.

Apesar de ser já noite, o maestro e os músicos não acenderam luzes sobre as estantes. A noite estava tão clara, que os lampiões, que ardiam na copa das tílias, haviam sido acesos, aparentemente, apenas para darem um toque de elegância à função.

Dágni escutava música clássica pela primeira vez. As peças executadas tinham um efeito estranho sobre ela. Todas as modulações e trons da orquestra suscitavam-lhe uma porção de quadros parecidos a sonhos. Depois, ela estremeceu e ergueu os olhos. Tivera a impressão de que o anunciador do programa, um homem magro, de cartola, pronunciara o seu nome.

- Foste tu que me chamaste, Nils? perguntou-lhe Dágni e imediatamente franziu o sobrolho.

Ele olhou para ela nem bem estarrecido, nem bem admirado. A tia, com o lenço à boca, olhava-a da mesma maneira.

- Que aconteceu? - perguntou Dágni.

Magda agarrou-lhe a mão e murmurou:

- Escuta!

Disse o homem de cartola:

- As pessoas das últimas filas pedem que eu repita. Será executada, agora, a famosa peça musical de Edvard Grieg dedicada a Dágni Pédersen, filha do guardabosques Haguerup Pédersen, pelo cumprimento dos seus dezoito anos.

Dágni respirou tão fundo, que até lhe doeu o peito. Com aquele suspiro, queria conter as lágrimas, que a sufocavam, mas não o conseguiu. Abaixou-se e escondeu o rosto entre as mãos.

No início, não ouvia nada. Dentro dela, rugia uma tempestade. Depois, ouviu, finalmente, cantar a flauta de um pastor na alvorada e uma orquestra de cordas responderlhe, após estremecer levemente. A melodia crescia, subia, furibunda como o vento, corria pelo topo das árvores, arrancava folhas, embalava as ervas, golpeava o rosto com salpicos frios. Dágni sentiu uma rajada de ar proveniente da música e acalmou-se.

Sim! Aquela era a sua floresta, a sua terra natal! As suas montanhas, as canções das trompas, o murmúrio do seu mar!

Barcos de vidro faziam espuma na água. O vento assobiava nos seus cordames. Esse som transformava-se imperceptivelmente no repique das campânulas da floresta, no silvo de pássaros, que davam cambalhotas no ar, em gritos de chamado de crianças, na canção de uma moça, a cuja janela o amado atirara um punhado de areia. Dágni ouvia essa cantiga nas suas montanhas.

Então, era ele! Aquele homem de cabelos brancos, que a ajudara a levar a cesta de pinhas de abeto para casa. Ele era EdvardGrieg, o mago e músico insigne! E ela ralhara com ele porque não sabia trabalhar depressa.

Eis, então, o presente, que ele prometera dar-lhe dez anos mais tarde!

Dágni derramava lágrimas de gratidão, sem ocultá-las. Neste ínterim, a música preenchia todo o espaço entre a terra e as nuvens, que pairavam sobre a cidade. $\mathrm{Po-}$ dia ver-se um leve encrespamento nelas, provocado pelas ondas melódicas. Através dele, brilhavam as estrelas.

A música já não tocava. Ela a chamava. Chamava-a para um mundo em que nenhuma amargura podia enfriar o amor, em que ninguém tirava a felicidade um do outro, onde o Sol ardia como uma coroa nos cabelos de uma fada benfazeja.

Na grande afluência de sons, soou, de repente, uma voz conhecida. "Tu és a felicidade-dizia. - Tu és o brilho da alvorada!"

Findou a música. Primeiro, devagar, depois, crescendo cada vez mais, estrondearam os aplausos.

Dágni levantou-se e foi rapidamente para os portões do parque. Todos se voltaram para olhá-la. A alguns ouvintes talvez houvesse ocorrido que aquela moça era a Dágni Pédersen, a quem Grieg dedicara a obra imortal.

"Ele morreu!-pensava ela. - Porquê?" Se fosse possível vê-lo! Se ele aparecesse ali! Com que coração disparado ela correria ao seu encontro, o abraçaria pelo pescoço, apertaria as faces molhadas de lágrimas às dele e diria apenas uma palavra: "Obrigada!". "Pelo quê?" - perguntaria ele. "Não sei... - responderia Dágni. - Por não ha- 
ver-me esquecido. Pela sua generosidade. Por haver-me mostrado o belo, de que devem viver as pessoas".

Dágni caminhava pelas ruas, desertas. Não notava Nils, que, mandado por Magda, a seguia, esforçando-se por não deixarse ver. Ele andava como um bêbado e balbuciava qualquer coisa sobre uma maravilha acontecida na vida obscura dos três.

A penumbra da noite cobria ainda a cidade. Nas janelas, porém, qual débil douradura, despontava já a alvorada setentrional.

Dágni chegou ao mar. Ele se estendia em um sono profundo, sem o menor murmulho de onda.

Ela apertou as mãos e suspirou do sentimento da beleza do mundo, ainda obscuro para ela própria, mas já senhor de toda ela.

- Escuta, vida - disse, baixinho -, eu te amo.

E começou a rir, olhando para as luzes dos navios, com os olhos muito abertos. Eles balouçavam suavemente, na água transparente e cinzenta.

Nils, que a espreitava a distância, ouviu o seu riso e foi para casa. Estava tranqüilo quanto a Dágni. Tinha certeza de que a vida dela não seria vivida em vão.

Serguiéi Aleksándrovitch Essiénin (1895-1925) - poeta, ainda hoie muito popular. Publicou o primeiro livro em 1916. Aderiu à Revolução de Outubro. Ligou-se à corrente futurista conhecida como imagismo. Em 1922, casou-se com a bailarina estadunidense Isadora Duncan, viajando, depois, com ela pela Europa e pelos Estados Unidos. Voltou sozinho à União Soviética no ano seguinte. Alcoólatra, entregou-se definitivamente à boêmia. Oficialmente, enforcou-se, na noite de 24 de dezembro de 1925, em um quarto do hotel Angleterre, de Leningrado, depois de cortar os pulsos e escrever um poema na parede, com o próprio sangue. Nos últimos anos, têm-se publicado livros que apresentam a tese de homicídio.

2 Em um tempo em que, no país, imperava o clima de intolerância, transcorriam, naquele estabelecimento, seminários de escritores muito diferentes entre si, pela natureza do talento e pela visão da vida. Se, por um lado, entre eles podia não haver o menor interesse recíproco, então, por outro, a sua influência e o seu conhecimento do mister produziam um meio cultural comum, porque eles representavam ajuda e um modelo de referência para as pessoas desejosas de apreender o espírito da literatura e tendentes a aunar os vários juízos em um conjunto de princípios de criação, que podiam combinar-se sem se fundirem. Não à toa Boris Pasternak (1890-1960) disse que o Instituto, fundado em 1933, fora o erro genial de Maksim Górki.

Muitos autores, que conquistaram fama a partir dos anos 50, como Vladímir Tendriakov (1923-84), lúri Trífonov (1925-81), lúri Kazakov (1927-82) Grigóri Baklánov (n. 1923) e lúri Bóndarev (n. 1924), havendo assistido aos seus seminários ou não, consideravam-no o seu mentor e reconheciam a influência, neles, da personalidade de Paustóvski, que lecionou ali, com alguns períodos de afastamento, de 1938 a 1949.

3 No mesmo ano, 1892, morreu o poeta Afanássi Fet (1820-92), e veio ao mundo a poetisa Marina Tsvetáeva (1892-1941). A Organização para a Educação, a Ciência e a Cultura, das Nações Unidas, decretou 1992 "o ano de Afanássi Fet, Marina Tsvetáeva e Konstantin Paustóvski". A asma minou a saúde do escritor, que, nos derradeiros anos, sofreu vários infartos. Faleceu em 14 de julho, em Moscou. O seu túmulo, modesto e simples como ele próprio, fica em um bosque, em Tarussa, cidadezinha tipicamente russa, às margens do Rio Oká

4 O Primeiro Ginásio de Kiev, dotado de excelentes professores, refletia bem a divisão das classes sociais. Dividia-se em duas seções: aristocrática e democrática. A primeira destinava-se aos filhos de generais, funcionários de alto posto no governo, financistas e aristocratas rurais; Paustóvski estudou na segunda, com meninos de famílias de polacos, judeus e rasnotchíntsi (no fim dos séculos XVIII e XIX, membros da intelliguéntsia não pertencentes à nobreza, oriundos de outras classes, como a pequena burguesia, o clero, o baixo funcionalismo e comerciantes). Foi nesse meio livre e barulhento que Paustóvski adquiriu o espírito independente de jovem de classe média baixa.

5 Em fevereiro de 1904, irrompeu a guerra russo-japonesa. As duas potências cobiçavam territórios da China e da Coréia e ambicionavam a hegemonia política no Extremo Oriente. O conflito, causa do aumento de impostos e da subida dos preços dos gêneros alimentícios, coincidiu com uma crise mundia de superprodução, seguida pela diminuição da produção e dos salários, e pela demissão em massa de trabalhadores.

Nesse quadro de piora violenta das condições de vida do povo e de indignação pela derrota certa, aconteceu a primeira revolução russa. Em 9 de janeiro de 1905, o tristemente famoso "domingo sangrento" de São Petersburgo, cossacos e a guarda imperial, por ordem do monarca, dispersaram à bala uma multidão de cento e quarenta mil pessoas, reunidas nas proximidades do palácio para entregar-the uma petição. A notícia da morte de quase um milhar delas e dos ferimentos de outras quatro mil provocou manifestações de protesto no país inteiro.

A organização reacionária União do Povo Russo formou as famigeradas "centúrias negras", grupos paramilitares de vendeiros, desocupados e ladrões, para ataques a sedes de sindicatos, caça a ativistas políticos e depredação de tipografias e redações de jornal. Em 7 de dezembro, ainda de 1905, cento e cinqüenta mil pessoas iniciaram, em Moscou, uma greve, logo transformada em insurreição armada, com muitos dias de combates de rua. 0 ano seguinte, em que, para a intimidação do povo, se colocaram forcas em praças públicas e estações ferroviárias, foi de mais greves, levantes operários e revoltas camponesas, esmagados, lentamente, um a um.

Apesar da derrota, a revolução de 1905-07 teve grande significado histórico, pois provocou o enfraquecimento do regime monárquico, possibilitando assim, a criação da Duma (Parlamento), o reconhecimento legal de sindicatos e partidos, e leis para a melhoria das condições de trabalho nas fábricas e nas minas. Vladímir Lênin chamou-the "ensaio geral" da revolução de 1917.

6 Paustóvski estreou na literatura em 1911, sob o pseudônimo K. Baláguin, com o conto "No Rio" ("Na Vodié"), publicado em uma revista de Kiev, quando era ainda aluno do liceu. Essa obra apontava já as direções futuras da sua prosa e traços que o tempo haveria de tornar expressivos. Além de trabalhar sobre a técnica e a linguagem, procurava o seu tema; sentia que escrevia ao arrepio da realidade e que precisava expressar a sua atitude em relação à vida e às pessoas; o amadurecimento aumentava a sua rejeição às fórmulas alheias. Ao comparar o produto da sua imaginação ao que planejara, ele, dotado de inegável cultura literária, não podia não sentir a disparidade das duas coisas.

O verdadeiro artista começa pela singularidade. A sua primeira meta consiste em descobrir a inclinação natural do seu talento, o campo mais favoráve ao desenvolvimento deste. Exercícios e sistemas de treinamento especial não encurtam o caminho, permitindo, na melhor das hipóteses, a criação de um estilo individual; o domínio da técnica, por si só, não traz a realização do escritor. Para atingir aquele objetivo, ele necessita de formar uma 
mundividência, uma mentalidade e, após isso, elaborar o modo de expressão mais ajustado ao próprio caráter. Já no outono de 1913, ao publicar o segundo conto, Paustóvski vira-se a braços com essa ingente tarefa, de ordem até mais psicológica do que técnica. Ele decidiu, então, deixar de escrever por dez anos; quis simplesmente viajar pelo mundo e conhecê-lo melhor, sem encarar os acontecimentos como material para futuro aproveitamento literário.

7 governo czarista calculou que a guerra, ao absorver as forças da classe trabalhadora e do campesinato pobre, enfraqueceria 0 movimento revolucionário; ela, pelo contrário, apenas agravou a situação social e política do país. Em meio a uma repressão policial encarniçada, os bolcheviques promoviam, entre soldados, camponeses e operários, uma atividade de esclarecimento da verdadeira essência do conflito, desmascarando a política das classes dominantes e pregando a deposição da monarquia.

Paustóvski recebeu com entusiasmo a Revolução de Fevereiro de 1917 e foi uma "testemunha atenta e interessada" da Revolução de Outubro, aceitando muitas coisas dela e rejeitando outras, principalmente o que the parecia desprezo à cultura do passado.

8 Figura singular da literatura russa deste século, que parece ocidental e, no entanto, saiu uma única vez da Rússia (e, ainda assim, só por alguns dias), Aleksandr Stepánovitch Grin (abreviação do sobrenome Griniévski) nasceu em 1880 e, até à morte, em 1940, teve de lutar diariamente com a necessidade; fazia serviços braçais, escrevia cartas para fregueses de botequim, pernoitava em albergues. Não obstante tudo isso, o sonho e o louvor à vida constituem a quinta-essência da sua obra, composta, toda ela, de luz, ventos marinhos e personagens de nomes estranhos aos ouvidos russos, a um tempo sonhadoras, rudes e temperamentais, capazes de correr sobre as ondas e voar.

Nos anos 30, 40 e 50, Paustóvski escreveu sobre Grin e pugnou pela sua reabilitação, conseguindo a publicação de obras suas e o recebimento dos direitos autorais pela sua viúva, recém-retornada da Alemanha, para onde fora levada como prisioneira, após a invasão da Criméia pelos nazistas.

9 Kara-Bugaz, nome de um golfo da costa oriental do Mar Cáspio, além de dar-the fama nacional, permitiu-the deixar o trabalho de jornalista e dedicarse inteiramente à literatura. Nele e nos outros livros, em que se misturavam ciência e ficção (Cólquida, de 1934, e O Mar Negro, de 1936), mais do que a luta para, entre outras coisas, explorar uma região remota ou pantanosa e conseguir melhorar espécies vegetais, comovia mais a luta das pessoas por um novo princípio moral.

Apesar de as duas primeiras novelas the haverem aberto a possibilidade de uma carreira fácil e uma vida tranqüila, Paustóvski virou as costas ao tema da edificação socialista, indiferente aos ataques dos detratores de sempre, que o acusavam, como a Mikhail Príchvin, de haver trocado a sociedade e a época por borboletas e árvores. Consciente de que a impetuosidade da industrialização e da urbanização causaria danos irreparáveis ao meio ambiente, reafirmou, nas obras posteriores, a necessidade de cuidado com todos os seres vivos e o valor moral e estético da natureza para a sociedade, enfim, que a verdadeira cultura implicava responsabilidade pela vida, e o futuro da humanidade refletiria o seu grau de harmonização com a natura. Proclamou tais idéias à época do desenvolvimento acelerado da União Soviética e nos duros anos do pós-guerra, quando precisou de muita coragem para continuar a falar da sua percepção da natureza, defendê-la e continuar a conclamar os compatriotas a não deixarem perder-se algo muito importante, que, apenas à primeira vista, os desviava das grandes tarefas sociais e econômicas de então.

10 Terras baixas, de florestas e pântanos secos (os mchári, que dão nome ao lugar), a leste de Moscou, na região de Riazan'.

11 No verão de 1918, o governo bolchevique fechou todos os jornais ditos "independentes". Paustóvski voltou à Ucrânia, ocupada pelos alemães, para buscar a mãe e a irmã, mas não conseguiu ir além de Kíev. Ele encontrou trabalho em um jornal e, depois, empregou-se em um depósito de tecidos. Após curto período sob a ocupação de tropas vermelhas, a cidade caiv em poder de um general branco, que decretou a arregimentação de todos os homens de até cinqüenta anos. Paustóvski fugiu para Odessa, esvaziada pela falta de comida e energia elétrica. Quando o poder soviético se estabeleceu ali definitivamente, a cidade achava-se insulada do Norte comunista lem redor, destruíram-se todas as estradas de ferro, e formara-se vasto território de ninguém, coalhado de bandos de salteadores) e passou o inverno de 1920 e o ano seguinte inteiro sob o bombardeio de navios estrangeiros. Vários países, como os EUA, a Inglaterra, a França e o Japão, intervieram na guerra civil (1918-22), com tropas e apoio material aos contra-revolucionários. Paustóvski ocupou, com alguns amigos, um sanatório abandonado e foi admitido como redator da gazeta de um sindicato. O salário, porém, chegava apenas para uma refeição diária. Ele e os companheiros tinham de completar o passadio com peixes e mariscos, arrancados à faca de rochedos da praia; no inverno, a sobrevivência impunha longas e perigosas excursões a localidades de veraneio, à cata de lenha para o forno de aquecimento do casarão. Apesar de tudo isso, em Odessa nasceu propriamente o escritor, estimulado pelo convívio com um grupo de representantes ilustres da primeira geração da literatura soviética: Isaak Bábel, Iliá Ilf, Evguiéni Petrov, lúri Oliécha e o poeta Eduard Bagrítski, entre outros.

120 epíteto "romântico", para a crítica soviética, significava viver em um mundo abstrato, restrito à arte, e não dar a mínima importância aos problemas e às idéias do seu tempo. Embora não tão ruim quanto "inimigo ideológico", aplicado a Mikhail Bulgákov, a Andriéi Platónov e muitos outros, podia fechar as portas das editoras ao autor. Os livros de Grin, por exemplo, foram declarados perniciosos à juventude e até retirados das bibliotecas. Paustóvski tratou temas de grande ressonância cívica, mas jamais aceitou seguir modelos e transformar-se em "auxiliar do Partido" e refletir, nas suas obras, as resoluções dos congressos partidários e as realizações dos indivíduos afanados em cumprir tais deliberações. Para ele, continuador das tradições humanísticas da literatura russa clássica, a qual tinha o homem no seu centro, a liberdade e o amor ao próximo deviam representar a bússola do código de consciência de todo escritor autêntico. Defendeu a legitimidade do romantismo na literatura dos duros anos posteriores à guerra e fez dele um estilo de luta e de afirmação de ideais.

13 Costuma-se designar por "paisagem" tudo o que a pessoa vê em torno de si e, também, a cópia pictórica do lugar, que oferece, à vista, elementos agradáveis à sua contemplação. Nós usamos a palavra nesta acepção: "Com esse termo se há de designar a cópia de um espetáculo da natureza pelas técnicas do desenho, da pintura ou da descrição literária. A paisagem acha-se no quadro ou nas páginas do livro, não no espetáculo da natureza. A paisagem nasce quando o espetáculo natural, passando da retina para a alma do observador, se projeta na tela ou no papel" (Raul Castagnino, Análise Literária, São Paulo, Mestre Jou, 1971, p. 106).

14 Tradução e notas de Noé Silva

15 Sniég. Publicado, primeiramente, na revista Ogoniók, de Moscou, em 1944

16 Diminutivo de Varvara.

17 Cidade da região metropolitana de Moscou.

18 Ópera de Piotr llítch Tchaikóvski (1840-93), com libreto do seu irmão M. Tchaikóvski, pela novela "A Dama de Espadas", de Aleksandr Serguiéevitch Púchkin (1799-1837).

19 Poema de Aleksandr Serguiéevitch Púchkin, musicado por Piotr llitch Tchaikóvski.

20 Niévidal' - algo nunca visto ou acontecido antes. Palavra usada em várias expressões (Kakáia niévidal' ! Vot niévidal'" ! Chto za niévidal' ! e outras), cujo sentido é: Grande coisa!

21 "Korzína c elórymi chíchkami". Escrito em 1953 e publicado, primeiramente, na revista Ogoniók, de Moscou, em 1954

22 Edvard Haguerup Grieg (1843-1907) - insigne compositor norveguês. A sua obra, de um romantismo maduro, é plena de um colorido de forte inspiração no populário da sua pátria. Nasceu em Bergen e morreu também ali.

23 Noites brancas - fenômeno observado na Escandinávia e no Norte da Rússia: noites estivais, em que ocorre a transição do crepúsculo vespertino diretamente para o matutino, sem que haja um período de escuridão entre eles.

24 Chapim - pequeno pássaro conirrostro, também chamado de mejengra (Parus coereleus). O nome provém do seu canto. 